\title{
Patchwork Protections: Progress and Problems in Battling Sexual Orientation Discrimination in Employment
}

\author{
Margaret S. Stockdale \\ Southern Illinois University Carbondale
}

Dwayne Simonton was a postal worker in Farmingdale, New York for 12 years. Despite regularly receiving satisfactory-to-excellent reviews of his job performance, he was repeatedly subjected to a hostile work environment because of his sexual orientation. His coworkers repeatedly made inflammatory and degrading comments to him, stating among other things that Simonton was a "f***ing faggot." Pornographic messages and materials were taped to his work area, sent to his home, and placed in his car. The abuses were so severe that Simonton eventually suffered a heart attack (Simonton v. Runyon, 2000).

Egregious harassment against sexual minorities, like that which Dwayne Simonton was forced to endure, is far too common. Research finds that both access and treatment discrimination among sexual minorities is prevalent (Black, Maker, Sanders \& Taylor, 2003; Button, 2001; Croteau, 1996). Yet, employment discrimination on the basis of actual or perceived sexual orientation remains one of the few socially important yet federally unprotected forms of discrimination.

Despite lack of federal protection, efforts have been made to protect against sexual orientation discrimination in employment among many states, counties, municipalities, and by private employers. Sexual minorities have to rely on this loose and leaky web of state and local laws as well as private initiatives to gain some assurances against employment discrimination. This article reviews the major trends in legal and employer-centered efforts to protect sexual minorities against employment discrimination, with a critical focus on the gaps and weaknesses provided by this patchwork set of protections. I call SIOP and its members to be leaders in a fight to end employment discrimination against sexual minorities.

\section{Legal Protections Against Sexual Orientation-Based Employment Discrimination: An Overview*}

\section{U.S. Constitutional and federal statutory efforts}

Although the 14th Amendment prohibits states from denying equal protection of the laws, states need only assert a rational reason for treating sexual minorities differently than others (Romer v. Evans, 1996). In Romer the U.S. Supreme Court struck down a publicly approved amendment to the Colorado constitution that would have prohibited any legislative, executive, or judicial action to ban discrimination on the basis of sexual orientation. Thus, it is unlawful for public employers to pass a law that would permit discrimi-

*I acknowledge a presentation by Gregory Nevins (2006) for the structure of most of this section. 
nation against sexual minorities. The court reached its decision by relying on a rational basis test, finding that no legitimate state purpose existed to engage in such discriminatory acts. Several employment discrimination cases against public employers have been decided in favor of the plaintiff as violations of the Equal Protection clause applying a rational basis standard (Miguel v. Guess, 2002; Lovell v. Comsewogue School Dist., 2002, Quinn v. Nassau County Police Dept., 1999), suggesting that courts are giving less deference to state interests than is typical when a rational basis test is applied.

Sexual minorities have also successfully raised First Amendment, free speech challenges in their employment discrimination claims (often in combination with other causes of action). Generally, employees tend to win cases when they have been subjected to an adverse employment decision for exercising their free speech rights, for example when they discuss their homosexual orientation outside the employment setting (Weaver v. Nobo School Dist., 1988); they advise students on the content of their academic writings (Marino v. Louisiana State Bd. of Sup'rs., 1997); or declare an intention to speak publicly about civil rights for homosexuals (Van Ooteghem v. Gray, 1981).

In addition to constitutional challenges, victims of sexual orientation discrimination have attempted, with limited success, to raise a Title VII claim of discrimination. Although courts have stated that Title VII does not apply directly to sexual orientation discrimination (see Bibby v. Philadelphia Coca Cola Bottling Co., 2001; Oncale v. Sundowner Offshore Services, Inc., 1998; Williamson v. A.G. Edwards and Sons, Inc., 1989), sexual minority plaintiffs who can prove that their discriminatory treatment was based on their gender or gender stereotypes have been able to make a Title VII claim (Heller v. Columbia Edwater Country Club, 2002; Rene v. MGM Grand Hotel, 2002). Nonetheless, many courts have refused to bootstrap a sexual orientation discrimination claim to a Title VII claim (see, e.g., Dillon v. Frank, 1992; Hamner v. St. Vincent Hospital and Health Care Center, Inc., 2000; Higgins v. New Balance Athletic Shoe, Inc., 1998; Williamson v. A.G. Edwards and Sons, Inc., 1989).

\section{State and local bans against sexual orientation employment discrimination}

Currently, 19 states and the District of Columbia prohibit employment discrimination on the basis of sexual orientation: California, Colorado, Connecticut, Hawaii, Illinois, Iowa, Maine, Maryland, Massachusetts, Minnesota, Nevada, New Hampshire, New Jersey, New Mexico, New York, Rhode Island, Vermont, Washington, and Wisconsin. However, some state statutes permit discrimination on the basis of sexual orientation and other classifications if there is a bona fide occupational qualification or need (e.g., California and Connecticut).

In addition to statutory protection, there is protection in several states through other devices such as executive orders (specifically Alaska, Arizona, Colorado, Delaware, Kentucky, Louisiana, Michigan, Ohio, and Pennsylvania) or policy statements (Indiana, Montana; National Gay and Lesbian Task Force, 2006). These provisions, however, only protect against sexual orienta- 
tion discrimination for public employment. Finally, as of 2005, there were city and county ordinances protecting against such discrimination for public employment in 42 states and for private employment in 29 states. (National Gay and Lesbian Task Force, 2006).

State constitutional arguments have also been successfully raised in sexual orientation discrimination cases. In Tanner v. Oregon Health Sciences University (1998), the Oregon appeals court found that the university's practice of denying employment benefits to same-sex partners, when they regularly extended benefits to opposite-sex partners of their employees, violated the state's constitution. However, this argument did not hold up in a California case (Hinman v. Department of Personnel Admin., 1985). The court reasoned that plaintiffs were not similarly situated as heterosexual partners with spouses but rather similarly situated as unmarried employees who are not entitled to such benefits (see also Rutgers Council of AAUP Chapters v. Rutgers, The State University, 1997).

\section{Gaps in legal protection}

The federal constitutional and statutory protections against sexual orientation discrimination in employment are limited. Fourteenth Amendment, Equal Protection arguments only apply to public employers, and the bar for mounting an Equal Protection challenge in employment discrimination is high. Plaintiffs must prove intention to discriminate for the purpose of causing adverse effects on the identified group (Schroeder v. Hamilton School District, 2002). First Amendment, free speech arguments only apply when a speech act is in question. If the gay employee is fired simply for being gay, no First Amendment claim can be made. Finally, federal statutory protection through Title VII is tenuous. Strong inferences of gender-based discrimination need to be established because animus on the basis of sexual orientation alone will fail in a Title VII action. Dwayne Singleton, for example, lost his Title VII claim because he could not adduce sufficient evidence that his harassment was based on gender stereotypes. Harassment based on sexual orientation alone does not offend Title VII. Thus, federal antidiscrimination protection for sexual minorities is a leaky sieve at best.

The patchwork of legal protections at the state and local level are also tenuous. As of July 2005 sexual minority citizens in Alabama, Arkansas, Mississippi, Nebraska, North Dakota, South Dakota, and Wyoming had nothing but weak U.S. Constitutional protection against employment discrimination. In several other states, protection is only provided to those who reside in certain cities and counties that passed antidiscrimination ordinances, and among these states only $41 \%$ of the ordinances apply to private employers (Gay and Lesbian Task Force, 2006). As noted in Rutgers (1997), some state courts have interpreted their antidiscrimination laws to preclude the extension of employee benefits to domestic partners, which is one of the main concerns 
for those who labor for equal rights for sexual minorities in the workplace (Lubensky, Holland, Wiethoff \& Crosby, 2004). For many, the quest for protection against employment discrimination has been left to reliance on employers' voluntary policies and practices.

\section{Private Employer Initiatives to Eliminate Sexual Orientation Discrimination}

Whereas laws against employment discrimination on the basis of sexual orientation are aimed at the protection of public welfare, private employer policies and practices seek ultimately to improve profitability and organizational viability. To remain competitive, savvy organizations adopt symbolic and practical initiatives that enhance their reputation as a good business and employer. Due to increasing pro-gay public sentiment and well-managed advocacy work of organizations such as The Human Rights Campaign (HRC) and Out and Equal in the Workplace, there has been catalytic growth in the number of companies that have adopted pro-gay policies and practices.

\section{Overview of employer policies and practices}

Researchers have conducted fairly comprehensive surveys of this population in an attempt to document the prevalence of employer pro-gay policies and initiatives. Button (2001) surveyed 537 gay and lesbian employees in 38 organizations in the U.S. and found that $95 \%$ of these organizations had a written nondiscrimination policy that included sexual orientation. Drawing a scientific sample of gay and lesbian employees who belong to gay civil rights organizations or Latino and African American gay rights organizations, Ragins and Cornwell (2001) reported that approximately 54\% of the respondents in their sample worked for an organization that had such a policy. HRC has been monitoring employer initiatives regarding sexual orientation among large companies and major law firms since 2002. Of the 492 companies rated in their latest survey, all but 10 had written nondiscrimination policies that included sexual orientation (HRC, 2006).

Pro-gay advocacy groups generally agree on a number of principles to guide employers' practices with regard to sexual orientation. These include not only widely disseminated policies against discrimination on the basis of sexual orientation but also extending health and other benefits to domestic partners, encouraging and supporting pro-gay affinity groups, sensitivity training, and nondiscrimination in advertising, promotions, sales, and services, among other practices (HRC, 2006).

HRC monitors large employers and publishes a Corporate Equality Index for each firm's score on these criteria. In 2006, 138 of the 492 organizations rated received a top score of 100, up from 102 organizations in 2005 and a ten-fold increase since the Equality Index was first measured in 2002 (HRC, 2006). Over half of Fortune 500 companies rated offered domestic partner 
health benefits to their employees, and there was a $34 \%$ increase in companies expanding their benefits. Industries with the highest Equality Index averages were hotels, resorts, and casinos; law firms; consulting and business services; aerospace and defense; and banking and financial services. Lowest industry averages were in advertising and marketing, automotive, mail and freight delivery, manufacturing, publishing and printing, and computer and data services (despite IBM having been the first U.S. company to promulgate a nondiscrimination policy that included sexual orientation in 1974; HRC, 2006).

To summarize, private employers are increasingly adding sexual orientation to their nondiscrimination policies as well as other practices that help send a message of support and appreciation for sexual minorities. Receiving national recognition for these efforts, such as high Corporate Equality Index scores from the HRC or "Outie" awards from Out and Equal in the Workplace, help drive the momentum for these initiatives.

\section{Gaps left open}

Despite these positive trends in the private sector, reliance on employer initiatives fails to resolve many problems for the full protection of sexual minorities against employment discrimination. First, employer initiatives are voluntary. Although there is increasing public pressure for organizations to adopt pro-gay policies and practices, there will always be a significant number of employers who offer no protection for and may actively discriminate against sexual minority employees.

Small-to-medium-size employers may not engage in voluntary employer initiatives to the same extent as large employers. HRC strategically targets the largest corporations in the U.S. with their Corporate Equality Index. By investigating and publishing the practices of America's largest employers, HRC hopes that those who "step up to the plate" will serve as industry leaders and that their direct competitors as well as other smaller organizations will follow suit (HRC, 2006). Small and medium-sized organizations tend to stay under the radar, and thus, little public pressure is brought upon them to engage in such practices.

Finally, there are potential legal problems with some aspects of employerbased initiatives, according to some commentators. For example, employers' efforts to sensitize employees to concerns of sexual minorities may be met with resistance from employees who hold sincere religious beliefs that homosexuality is immoral and thus invoke their Title VII right to a religious accommodation.

Kaplan analyzed three federal cases where an organization's diversity initiatives clashed with employees' religious beliefs (Kaplan, 2006). In Altman v. Minnesota Department of Corrections, (2001) employees were mandated to attend gay-sensitive interpersonal interaction training. When the employer did not respond to plaintiffs' request for a religious accommodation, plaintiffs engaged in civil disobedience by reading their bibles during training. In response to their actions, the employer put letters of reprimand in the employees' personnel files, which adversely affected future promotions. However, 
there was a fairly broad range of employer activity that the courts found acceptable in Peterson v. Hewlett-Packard (2004) and Williams v. Kaiser Permanente Div. of Research (2000). For example, unavoidable exposure to posters in the workplace promoting diversity that included sexual orientation, training programs that focused primarily on the advantages of sexual orientation sensitivity for attracting customers, and termination of employees who continued to protest after being offered reasonable religious accommodations was associated with pro-employer decisions (Kaplan, 2006). Although employers appear to have some latitude in promoting diversity initiatives that incorporate sexual orientation, they need to be cognizant and appreciative of employees' sincerely held religious beliefs that may conflict with these efforts.

\section{What Can SIOP and I-O Psychologists Do?}

As experts in the science of employment discrimination and in the development of human resource practices that place the dignity of individuals at the forefront, I-O psychologists should have a strong voice in efforts to broaden and patch the holes in employment discrimination protection for sexual minorities. As scientists, we should continue to do research on the forms and nuances of bias and prejudice against sexual minorities, as well as evaluate the efficacy of organizational practices that affect important outcomes for sexual minorities. As practitioners, we should work closely with our clients' leaders to craft policies, practices, training, and other programs to consciously address the concerns of sexual minorities. SIOP can lend expertise to scientific and policy making panels that may be commissioned to study the concerns of employment discrimination against sexual minorities. Finally, as individuals, we can each urge our elected representatives to pass legislation, such as The Employment Non-Discrimination Act (ENDA; 2007) at the federal level. This paper ends with a quote from the Senate Report of ENDA (2002), which remains as compelling today as it did 6 years ago:

Congress must pass the Employment Non-Discrimination Act to fill a gaping hole in the fabric of Federal civil rights legislation. Title VII prohibits discrimination based on race, color, religion, sex and national origin - but not sexual orientation. This leaves gay, lesbian, and bisexual Americans - as well as heterosexual Americans - reliant on a patchwork of legal protections inadequate to address the problem of sexual orientation discrimination in employment in a uniform, predictable, fair and reliable manner. (U.S. Senate Report 107-341)

\section{References}

Altman v. Minnesota Department of Corrections, 251 F. 3d, 1199 (2001).

Bibby v. Philadelphia Coca Cola Bottling Co., 260 F.3d 257 (3d Cir. 2001).

Black, D. A., Makar, H. R., Sanders, S. G., \& Taylor, L. J. (2003). The earnings effects of sexual orientation. Industrial and Labor Review, 56, 449-469. 
Button, S. B. (2001). Organizational efforts to affirm sexual diversity: A cross-level examination. Journal of Applied Psychology, 86, 17-28.

Croteau, J. M. (1996). Research on the work experiences of lesbian, gay and bisexual people: An integrative review of methodology and findings. Journal of Vocational Behavior, 48, 195-209.

Dillon v. Frank, 1992 U.S. App. LEXIS 766 (6th Circuit 1992).

Hamner v. St. Vincent Hospital and Health Care Center, Inc., 224 F.3d 701, 707 (7th Circuit 2000).

Heller v. Columbia Edwater Country Club, 195 F. Supp. 2d 1212 (D. Or., 2002).

Higgins v. New Balance Athletic Shoe, Inc., 21 F. Supp. 2d 66 (D. Me. 1998).

Hinman v. Department of Personnel Admin., 167 Cal.App.3d 516 (Cal.App. 3 Dist., 1985).

Human Rights Campaign Foundation. 2006 Corporate Equality Index report. Retrieved Nov. 6, 2006 at www.hrc.org (2006).

Kaplan, D. M. (2006). Can diversity training discriminate? Backlash to lesbian, gay, and bisexual diversity initiatives. Employee Responsibilities and Rights Journal, 18, 61-72.

Lovell v. Comsewogue School Dist., 214 F. Supp. 2d 319 (E.D.N.Y. 2002).

Lubensky, M. E., Holland, S. L., Wiethoff, C., and Crosby, F. J (2004). Diversity and sexual orientation: Including and valuing sexual minorities in the workplace. In M S. Stockdale \& F. J. Crosby (Eds.), The psychology and management of workplace diversity (pp. 206-223). Oxford, UK: Blackwell.

Marino v. Louisiana State Bd. of Sup'rs, 1997 WL 358141 (E. D. LA).

Miguel v. Guess, 51 P.3d 89 (Wn. Ct. App. 2002).

National Gay and Lesbian Task Force. 2006. States, cities and counties with civil rights ordinances, policies or proclamations prohibiting discrimination on the basis of sexual orientation (current through July 2005). Retrieved Nov. 6, 2006 from http://www.thetaskforce.org/downloads/ FAIRAmicus-LocalLawsTable.pdf

Nevin, G. R. (2006). Litigating LGBT employment cases in the red states. Accessed November 7, 2006 at http://www.lavenderlaw.org/docs/CD/Concurrent\%20Workshops\%20-\%20Session $\% 20$ Five $\% 20-\% 20$ Bringing $\% 20$ Employment $\% 20$ Discrimination $\% 20$ Cases $\% 20$ in $\% 20$ the $\% 20$ Red $\% 20$ States.ppt.

Oncale v. Sundowner Offshore Services, Inc.(1998) (523 US 75).

Peterson v. Hewlett-Packard, 358 F. 3d 599 (2004).

Quinn v. Nassau County Police Dept. 53 F. Supp. 2d 347, 350 (E.D.N.Y. 1999).

Ragins B. R. \&. Cornwell, J. M. (2001). Pink triangles: Antecedents and consequences of perceived workplace discrimination against gay and lesbian employees. Journal of Applied Psychology, 86, 1244-1261.

Rene v. MGM Grand Hotel, 305 F. 3d 1061 (C.A. 9 (Nev.) 2002).

Romer v. Evans, 517 U.S. 620 (1996).

Rutgers Council of AAUP Chapters v. Rutgers, The State University, 298 N.J.Super. 442, 460-462, (N.J.Super.A.D.,1997).

Schroeder v. Hamilton Sch. Dist., 282 F.3d 946, 951 (7th Cir. 2002).

Simonton v. Runyon, 232 F.3d 33, 35 (C.A.2 (N.Y.) 2000).

Tanner v. Oregon Health Sciences Univ., 157 Ore. App. 502 (Or. Ct. App. 1998).

The Employee Non-Discrimination Act of 2002, S. 1284. Retrieved Nov. 25, 2006 from http://thomas.loc.gov/cgi-bin/bdquery/z?d108:s.01705

The Employee Non-Discrimination Act of 2007, H.R. 2015. Retrieved September 20, 2007 from http://thomas.loc.gov/cgi-bin/thomas

U.S. Senate Report 107-341. Retrieved Nov. 26, 2006 from http://thomas.loc.gov/ cgi-bin/cpquery/z?cp107:sr341

Van Ooteghem v. Gray, 654 F. 2d 304 (C. A. Tex., 1981) (en banc).

Weaver v. Nobo School Dist., 29 F. Supp 2d 1279 (D. Utah, 1988).

Williams v. Kaiser Permanente Div. of Research, C-99-4230 MJJ (2000).

Williamson v. A.G. Edwards and Sons, Inc., 876 F.2d 69, 70 (8th Circuit 1989). 